\title{
Rate of Degradation and Efficiency of Conversion of Phytoplankton Debris by Marine Micro- Organisms
}

\author{
R. C. Newell, M. I. Lucas and E. A. S. Linley \\ Institute for Marine Environmental Research, Prospect Place, Plymouth PL1 3DH, United Kingdom
}

\begin{abstract}
Detritus from the dinoflagellates Scrippsiella (= Peridinum) trochoidea and Isochrysis galbana and from the diatoms Skeletonema costatum. Thalassiosira angstii and Chaetoceros tricornutum incubated at $10^{\circ} \mathrm{C}$ in seawater is colonised by a succession of micro-organisms. Primary microbial decomposers in the incubation experiments were bacterial rods and cocci which reached a peak standing stock carbon of $1.86 \pm 0.76 \%$ of the carbon supplied to the incubation media by the third day of incubation. The bacteria were subsequently replaced by flagellates which attained a mean peak biomass of $12.5 \pm 3.58 \%$ of the bacterial biomass by Day 6 before declining. Synchronous measurement of the utilisation of dissolved and particulate components from the incubation media shows that there is a well-defined initial sequence of aggregation of particulate matter to form bacterioparticulate complexes, much as have been recorded for natural waters. During this phase, carbon is mainly utilised from the dissolved component of phytoplankton cell debris, whilst the more refractory components including particulate debris is used more slowly. The dissolved organic component comprises a mean of $34.24 \%$ of the total carbon in the debris and has a $50 \%$ utilisation time of only $1.56 \mathrm{~d}(37.44 \mathrm{~h})$, whereas the particulate component comprises $65.76 \%$ of the total carbon and has a $50 \%$ utilisation time of as much as $11.56 \mathrm{~d}(277.4 \mathrm{~h})$. Bacterial carbon conversion efficiency (bacterial carbon/detrital carbon used $\times 100$ ) during the initial phases of colonisation is $9.8 \%$-a value similar to that recorded for bacterial conversion of dissolved components of macrophyte debris. The results suggest that the carbon conversion budget for the decomposition of phytoplankton cell debris is $100 \mathrm{~g}$ carbon yielding $4 \cdot 644 \mathrm{~g}$ of bacterial carbon. This value for incorporation of carbon into bacteria from phytoplankton cell debris is much lower than might be anticipated from the absorption efficiency of selected labile components released in small quantities by living phytoplankton. The carbon conversion budget for whole phytoplankton debris thus suggests that as much as $30.8 \%$ of the carbon is mineralised and returned to the environment within $3 \mathrm{~d}$ by the bacteria which initially colonise the material, whereas the more refractory $64.4 \%$, comprising carbon in the particulate components of the cell debris, is mineralised within approximately $11 \mathrm{~d}$ by bacteria characteristically associated with the decomposition phase of a phytoplankton bloom.
\end{abstract}

\section{INTRODUCTION}

Utilisation of organic matter by marine microheterotrophs has received considerable attention in recent years. Most earlier work reported that bacterial growth on phytoplankton cell surfaces occurs only during the decomposition phase of phytoplankton blooms (Droop and Elson, 1966; Sieburth, 1968; Bell and Mitchell, 1972; Bell et al., 1974) often leading to aggregation and the formation of detrital clumps (Hobbie et al., 1972; see also Linley and Field, 1981). Subsequent work suggested that the release of extracellular dissolved organic matter from living phytoplankton cells may also be of significance as a substrate for the growth of microheterotrophic organisms (for reviews see Fogg, 1971; Hellebust, 1974). Very variable values of exudate release from $0-75 \%$, but generally less than $40 \%$ of the photoassimilated carbon have commonly been recorded for marine phytoplankton (Hellebust, 1965; Horne et al., 1969; Anderson and Zeutschel, 1970; Samuel et al., 1971; Thomas, 1971; Berman and Holm-Hansen, 1974; Smith, 1974; Iturriaga and Hoppe, 1977). Partly because of the variability in reported values for the release of dissolved organic matter by phytoplankton cells under differing conditions, some doubts have been expressed about the 
amounts of dissolved organic matter which are released from healthy phytoplankton under natural conditions in the sea (Sharp, 1977). Nevertheless much recent work suggests that the release of small quantities of dissolved substances from marine phytoplankton may be of regular occurrence in normal healthy cells (Smith et al., 1977; Mague et al., 1980).

Of this material, however, only a relatively small proportion may be labile and readily utilisable by microheterotrophic organisms whilst the remainder is refractory (Andrews and Williams, 1971; Yurkovsky, 1971; Ogura, 1972, 1975; Allen, 1973; Ogura and Gotoh, 1974; Wiebe and Smith, 1977; Larsson and Hagström, 1979). Such studies indicate that some $10-25 \%$ of the total dissolved organic matter - but commonly as little as $0.1 \%$ (Wiebe and Smith, 1977 ; Larsson and Hagström, 1979) - may comprise the labile fraction. This is generally assumed to represent mainly free sugars and amino acids and is often capable of rapid heterotrophic uptake by bacteria at a rate which is comparable with its rate of release from the phytoplankton. Our knowledge of the turnover and microbial utilisation of such compounds is mainly based on experiments with ${ }^{14} \mathrm{C}$-labelled substrates, and these have given some insight into the dynamics of bacterial uptake of simple labile components of dissolved organic matter in natural waters (Wright and Hobbie, 1965; Hobbie, 1967; Hobbie and Crawford, 1969; Gordon et al., 1973; Crawford et al., 1974; Fenchel and Jørgensen, 1976). But it is clear that the results of kinetic studies on the uptake of simple organic substrates are likely to apply to only the relatively small labile component of the photoassimilated carbon released during the decomposition phase of a phytoplankton bloom. Nevertheless, uptake and respiration of labelled organic substrates by natural populations of microheterotrophs have allowed calculation of apparent 'growth yields' of such populations obtained by division of the amount of substrate incorporated into the organism per unit time (the net uptake) by the total uptake (net uptake + respired ${ }^{14} \mathrm{C}$ ) (Williams, 1970, 1973).

More recently, Billen et al. (1980) have used similar data to calculate the 'yield constant' ( $y$ ) which expresses the number of bacteria formed per mole of simple ${ }^{14} \mathrm{C}$-labelled substrate incorporated: $y=\alpha / C$, where $\alpha$ is the 'growth yield' described above and represents the part of the total substrate taken up for biosynthetic purposes, and $C$ the carbon content of a single cell. Billen et al. reported very variable values of $\alpha$ for a number of simple organic substrates, with a mean of $0.3-0.4$. Values for $C$ are $0.25-0.5 \times 10^{-8} \mu \mathrm{mol}$ of carbon per bacterium (Stanier et al., 1970). From these values can be calculated that the yield constant $(y)$ is approximately $10^{8}$ bacteria per micromol of carbon, although it should be emphasised that these estimates can be easily applied to only a very small labile component of the dissolved organic matter released, and that the incorporation rates of even these simple organic substrates are subject to considerable variability (Billen et al., 1980).

An alternative approach is to measure the increase in microheterotrophs in the presence of algal debris by means of acridine orange direct counts (AODC) and to express the biomass of bacteria or bacterial carbon directly as a function of carbon utilised from the debris (Linley et al., 1981; Linley and Newell, 1981; Lucas et al., 1981; Newell and Lucas, 1981; Stuart et al., 1981). This has the advantage that the carbon conversion efficiency' of the complex dissolved and particulate components released during the decomposition of marine algae can be measured more-or-less directly, and also allows estimation of the rate of degradation of dissolved and particulate components of the debris. The results suggest that bacteria initially utilise the dissolved organic components released during the decomposition phase of a phytoplankton bloom and that incorporation of these substances may be considerably lower than that reported for simple labile organic substrates.

\section{MATERIAL AND METHODS}

\section{Incubation and Sampling Procedure}

A variety of phytoplanktonic organisms, represented by the thecate dinoflagellate Scrippsiella (= Peridinium) trochoidea, the athecate form Isochrysis galbana and the diatoms Skeletonema costatum, Thalassiosira angstii and Chaetoceros tricornutum were used as source material for phytoplankton decomposition experiments between November 1980 and February 1981. Approximately 41 of cell suspension in the later log phase of growth were sedimented by centrifugation during which the cells were found to have remained intact. The sediment from each phytoplankton source was resuspended in $250 \mathrm{ml}$ distilled water, frozen and thawed - a procedure which could be seen under the microscope to have disrupted the cells (see also Fig. 1a); 2.01 of freshly-collected seawater from outside the Plymouth Breakwater were filtered through a $20 \mu \mathrm{m}$ sieve to remove larger Protozoa and grazing zooplankton; $1.5 \mathrm{l}$ was then placed in each of a series of $10 \times 2$ l sterilised flasks and sufficient suspension of disrupted cells added to bring the total carbon concentration to $12-15 \mathrm{mg} \mathrm{l}^{-1}$ for each source material. This value was selected because it is comparable to the carbon equivalent of maximal chlorophyll concentrations likely to be found immediately prior to 
the decomposition phase of dinoflagellate blooms at frontal systems in the English Channel (P. M. Holligan, Marine Biological Association, Plymouth, U. K.: personal communication).

Apart from 5 active incubation flasks, the experimental series comprised a control vessel for each of the phytoplankton types filled with an inoculum of the same stock and concentration, to which sodium azide was added to a final concentration of $0.02 \% ; 1.5 \mathrm{ml}$ of a $20 \%$ solution of sodium azide was also added on alternate days to the control vessels to suppress bacterial growth. An additional control vessel containing $1.5 \mathrm{l}$ of $20 \mu \mathrm{m}$ filtered seawater, but no phytoplankton debris, was included in the series. Air was pumped separately through a $0.2 \mu \mathrm{m}$ Nuclepore filter to each pair of experimental and control vessels to keep particulate matter in suspension and to maintain aerobic conditions in the culture media. The outlet tubes were plugged with a cellulose wool filter to minimise contamination from the air.

The vessels were then placed on an orbital shaker and held at $10^{\circ} \mathrm{C}$ in the dark for up to 4 weeks. Samples of the incubation media for all vessels were taken at time zero and at intervals of $6 \mathrm{~h}$ for $2 \mathrm{~d}, 12 \mathrm{~h}$ for a further $2 \mathrm{~d}, 24 \mathrm{~h}$ for an additional $4 \mathrm{~d}$, then at intervals of $7 \mathrm{~d}$. Samples of $20 \mathrm{ml}$ were withdrawn with sterilised syringes for microbial estimations and $25 \mathrm{ml}$ samples were also taken with sterilised syringes for combined estimations of particulate matter and carbon analyses.

\section{Microbial Numbers and Biomass}

The samples taken from the vessels were transferred to autoclaved glass scintillation vials containing sufficient glutaraldehyde fixative to bring the final concentration to $2.5 \%$. The numbers of microorganisms on $0.2 \mu \mathrm{m}$ Nuclepore filters following filtration of $1.5 \mathrm{ml}$ medium were then estimated by the acridine orange direct count (AODC) technique (Hobbie et al., 1977; Daley, 1979; Linley et al., 1981). Formation of aggregates in the incubation media made accurate counts difficult. In media where aggregation had occurred, 1 to $5 \mathrm{ml}$ of the fixed samples were incubated for approximately $5 \mathrm{~min}$ with an equal volume of $5 \mathrm{mg} \mathrm{l}^{-1}$ sodium tripolyphosphate solution (Pike et al., 1972) and sonicated for $30 \mathrm{~s}$ in a Dawe Sonicleaner Type $6441 \mathrm{~A}$ prior to staining with acridine orange. Microbial biomass was calculated from cell numbers and mean volumes measured by means of the scanning electron microscopy method described by Linley et al. (1981). The dimensions of 20 to 60 cells in up to 5 random fields were measured and cell volumes subsequently obtained by using a Kontron Mop Digitiser interfaced to a SWTP M 6809 Micro-computer-system. Because mean cell volumes and relative numbers of rods and cocci varied during the course of the incubation, the cell dimensions of rods, cocci and flagellates were estimated on a daily basis throughout the experimental period. Linley (unpubl.) has made a detailed comparison of methods used in measuring the cell dimensions of bacterial isolates and concluded that shrinkage during preparation for SEM amounted to a mean of $7.6 \%$ of the final cell volume. All values for cell volumes were corrected for shrinkage using values of $8.4 \%$ for rods and $5.9 \%$ for cocci.

The dry biomass and carbon equivalent of wet biomass were then calculated from the numbers and cell volumes using values for specific gravity cited by Calkins and Summers (1941) and Luria (1960) and the coefficients of 0.2 and 0.1 for the dry biomass and carbon equivalents of the wet biomass respectively (Luria, 1960; Troitsky and Sorokin, 1967; see also Sorokin and Kadota, 1972). A carbon equivalent of $50 \%$ of the dry biomass is commonly used (Luria, 1960) and is a value which we have adopted here and elsewhere. Nevertheless, some of our own measurements on crude bacterial preparations from kelp debris suggest that the carbon may be only $30-40 \%$ of the dry biomass. Similarly, Ferguson (personal communication: NOAA southeast Fisheries Center, Beaufort, N.C.) has found values of only $34 \%$ for the carbon equivalent of the dry biomass of bacteria from Spartina marshes. Our estimates of carbon incorporation into bacteria are therefore likely to be maximal ones which more then offset the effects of shrinkage on our estimates of cell dimensions.

\section{Particulate Matter}

The $25 \mathrm{ml}$ of incubation medium removed from each vessel for particulate and carbon analysis were placed in clean glass scintillation vials, shaken and 3 separate $1 \mathrm{ml}$ aliquots removed for particle counting. Each was made up to $50 \mathrm{ml}$ with $0.45 \mu \mathrm{m}$ filtered seawater. Particle size distribution was then estimated on $3 \times 0.5 \mathrm{ml}$ aliquots of each of the three diluted samples by means of a Coulter Counter Model TA II with population accessory and a $100 \mu \mathrm{m}$ orifice tube. Counts were expressed as the difference between the experimental media and filtered seawater over the channel range 3 to 15 inclusive. This yielded an effective assay spectrum of $2.0-40.3 \mu \mathrm{m}$ lower channel edge diameter. Particle concentration was then expressed as ppm by volume (Strickland and Parsons, 1972) and plotted as a function of particle diameter and incubation time by means of a multidimensional graphics system (University of Cape Town, Computer Centre). 


\section{Carbon Analysis}

Samples of $20 \mathrm{ml}$ of incubation medium were filtered under vacuum through a pre-ashed $\left(400^{\circ} \mathrm{C}\right.$ for $\left.6 \mathrm{~h}\right)$ $1.2 \mu \mathrm{m} \mathrm{GF/C} \mathrm{Whatman} \mathrm{glass} \mathrm{fibre} \mathrm{filter} \mathrm{of} 25 \mathrm{~mm}$ diameter. The filter was oven dried at $55^{\circ} \mathrm{C}$ overnight and retained in a desiccator for particulate carbon analysis. Triplicate aliquots of $5 \mathrm{ml}$ of the filtrate were transferred to precombusted $10 \mathrm{ml}$ glass ampoules to which $50 \mu \mathrm{l}$ of $1 \mathrm{~N} \mathrm{HCl}$ made up in carbon-free distilled water was added. The ampoules were then sealed and stored in a deepfreeze prior to analysis.

The dried GF/C filter plus particulate carbon was weighed on a Cahn 25 automatic electrobalance and crushed to powder in an agate ball mill. Three weighed subsamples of 5 to $6 \mathrm{mg}$ were then transferred into dry tin micro-cups which had been previously cleaned with chloroform, acetone and distilled water to remove carbon, and were placed into the sampler of a Carlo Erba elemental (CHN) auto-analyser (Model 1106) fitted with an integrator to give carbon and nitrogen peak areas. The nitrogen and carbon content of 5 blank samples of tin cups alone, and of the triplicate experimental samples, was then calculated from the mean peak areas of 10 weighed samples of approximately 1.5 to $2.0 \mathrm{mg}$ cyclohexanone (Carlo Erba) which contains $20.14 \%$ nitrogen and $51.79 \%$ carbon.

After the addition of a further $75 \mu \mathrm{l} \mathrm{N} \mathrm{HCl}$ to the frozen ampoules to ensure that carbon dioxide from inorganic sources had been released, the dissolved organic carbon remaining in the acidified filtrates was measured by the method of Collins and Williams (1977) as modified by Gershey et al. (1979). Carbon is photo-oxidised with $\mathrm{u} / \mathrm{v}$ radiation and the resultant $\mathrm{CO}_{2}$ is carried on a carbon-free oxygen stream through a gas stripper, dried with Hydranone, and measured with an infra-red $\mathrm{CO}_{2}$ analyser. Hydroxylamine hydrochloride was added to the photo-oxidised sample to reduce chlorine gas to chloride, since the former interferes with $\mathrm{CO}_{2}$ detection, whilst the addition of more $2 \mathrm{~N} \mathrm{HCl}$ after photo-oxidation ensured a low $\mathrm{pH}$ of $<2.0$ and quantitative removal of $\mathrm{CO}_{2}$ from the liquid stream. Standards of $0.7678 \mathrm{~g}$ Analar potassium oxalate dissolved in $100 \mathrm{ml} \mathrm{u} / \mathrm{v}$ oxidised distilled water to yield $1 \mathrm{mg} \mathrm{C} \mathrm{ml}^{-1}$ were used throughout the analyses.

\section{RESULTS}

\section{Micro-Organisms Associated with the Degradation of Phytoplankton Debris}

The freshly collected seawater to which the cell debris was added typically contained a bacterial cell density of $2.1-4.6 \times 10^{5}$ cells $\mathrm{ml}^{-1}$ comprising approxi- mately $34 \%$ bacterial rods with a mean volume of $0.08 \pm 0.04 \mu \mathrm{m}^{3}$ and $66 \%$ cocci with a mean volume of $0.046 \pm 0.022 \mu \mathrm{m}^{3}$. A characteristic microbial succession comprising an initial increase in bacteria which reached as much as $2.28 \times 10^{7}$ cells $\mathrm{ml}^{-1}$ by Day 3 , followed by an increase in numbers of micro-flagellates with a corresponding decline in bacteria, occurred in all incubation media, much as we have described in the incubation of macrophyte debris (Linley et al., 1981; Linley and Newell, 1981: Stuart et al., 1981). The mean volume of the flagellates was $16.87 \pm 4.45 \mu^{3}$ but in all media a wide variety of sizes ranging from 3.82 to $42.94 \mu \mathrm{m}^{3}$ was recorded.

Samples taken initially from the incubation media showed that the phytoplankton cells had been disrupted and that free-living bacteria dominated the assemblage, presumably utilising the lysed contents of the cells (Fig. 1a). Subsequently the bacterial numbers increased and there was a reduction in variety of morphological types resulting in the development of a roddominated assemblage by Day 3 (Fig. 1b). After approximately $4 \mathrm{~d}, \mu$-flagellates with a mean volume of approximately $17 \mu^{3}$ became common (Fig. 1c) and reached a peak density by Day 6 during which time the bacteria had declined, presumably due to the grazing activities of the flagellates (Fenchel, 1970; Linley et al., 1981; Linley and Newell, 1981). It is noteworthy that the flagellates increased in numbers only after the bacteria had attained a peak biomass and it seems possible that a critical prey density may be required to initiate logistic growth in the flagellates.

By Day 8 , the reduced numbers of free-living bacterial rods were replaced by rather larger rods associated with the particulate fraction. Thread-like strands or fimbriae were commonly seen at this stage and in some instances, as in the Thalassiosira angstii debris, stalklike caulobacters were observed attached to the debris (Fig. 1d and f). Complex aggregates formed from particulate material (Fig. 1e) became common in the incubation media, but not in the sterilised control vessels. At this stage the microbial community became more complex with the appearance of choanoflagellates, ciliates and amoeboid forms, all of which were generally associated with the aggregates (see also Linley and Newell, 1981; Stuart et al., 1981). Aggregate formation thus appears to be a process initiated by bacterial growth and adhesion to the particulate fraction of cell debris.

\section{Microbial Numbers and Biomass}

The effects of addition of detrital carbon on the numbers of bacteria and flagellates in seawater incubated at $10^{\circ} \mathrm{C}$ are summarised in Table 1 . The concentrations of carbon added were $12.1 \mathrm{mg} \mathrm{l}^{-1}$ from Thalas- 


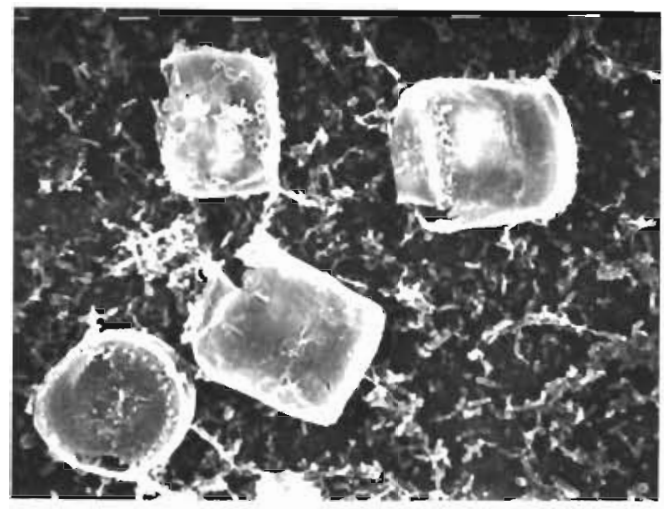

a
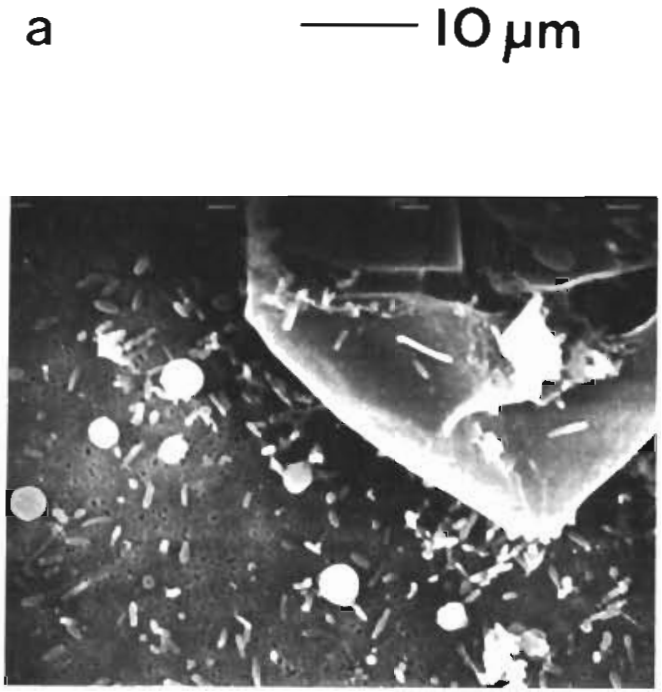

C

$5 \mu \mathrm{m}$

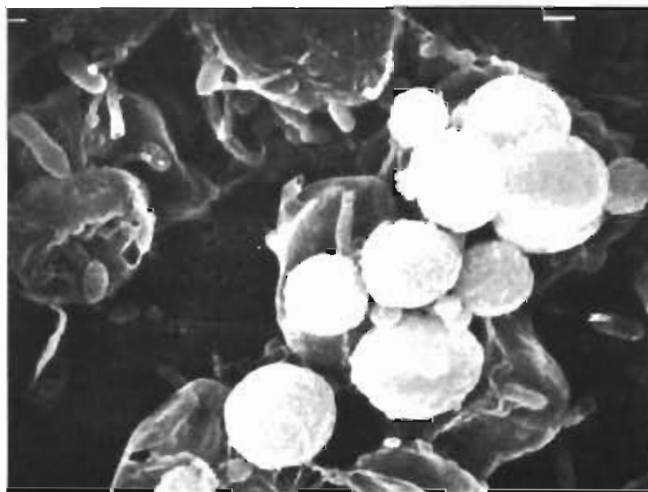

e

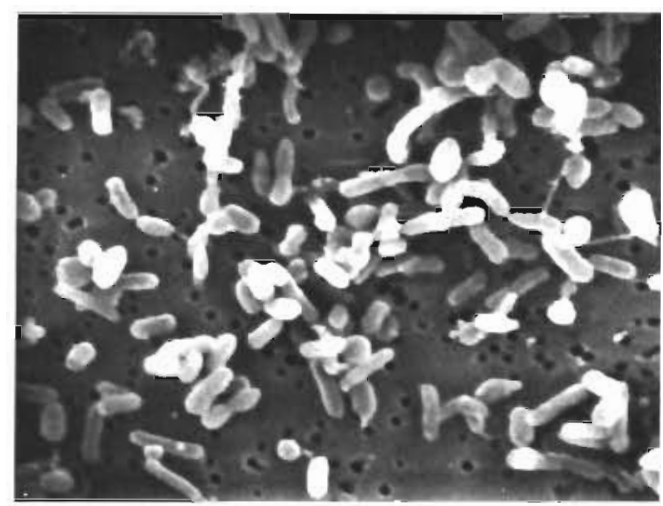

b

$2 \mu \mathrm{m}$
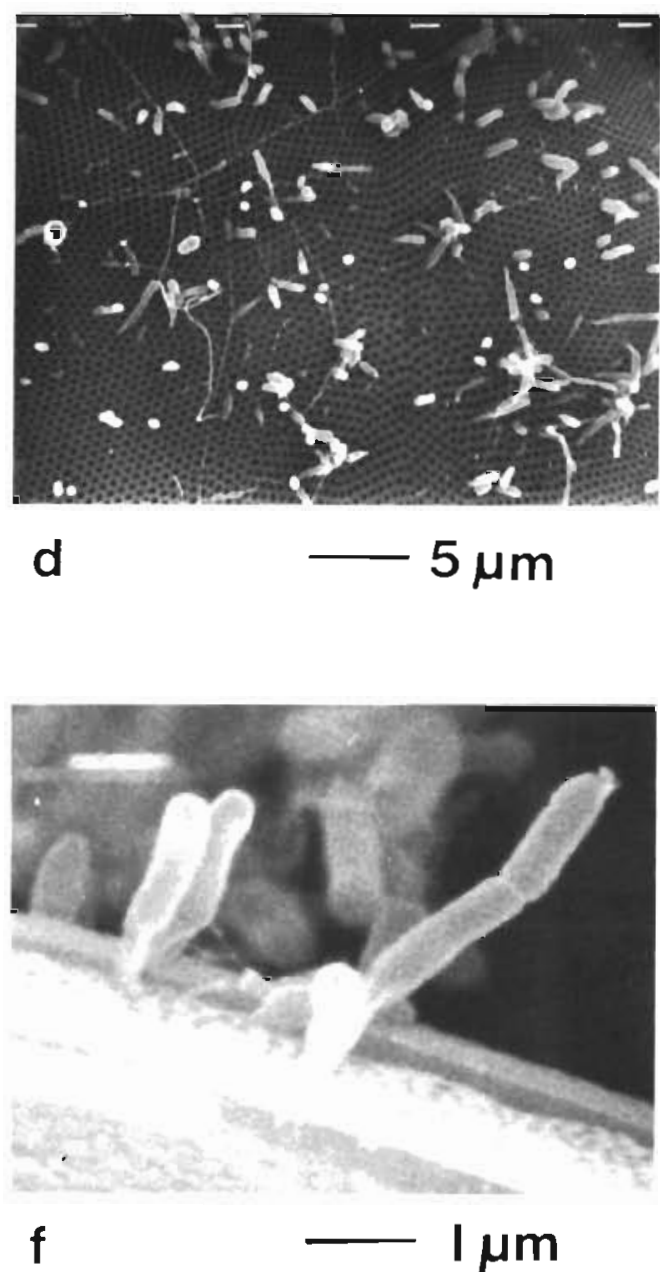

Fig. 1. Selection of the micro-organisms which colonise seawater incubated with phytoplankton debris at $10{ }^{\circ} \mathrm{C}$. (a) Thalassiosira angstii cell debris showing disrupted cells and initial colonisation of the incubation medium by a mixed population of free-living rods and cocci. (b) Free-living, rod-dominated assemblage in a Skeletonema costatum incubation medium on Day 3 . (c) Mixed population of $\mu$-flagellates and free-living bacteria associated with Scrippsiella trochoidea debris (Day 4 ). (d) $T$. angstii cell surface showing attached bacteria. (e) Partially dispersed aggregate revealing attached bacteria and $\mu$-flagellates (Day 7 ). (f) Stalked caulobacters attached to cell debris from $T$. angstii 
Table 1. Maximal values for bacterial numbers (cells $\mathrm{ml}^{-1} \times 10^{6}$ ) and flagellates (cells $\mathrm{ml}^{-1} \times 10^{4}$ ) in seawater incubated at $10^{\circ} \mathrm{C}$ with a variety of phytoplankton debris. The proportional increase in bacterial numbers over the initial values for the seawater and time of occurrence of the peaks is also shown. Data summarised from 2 experimental series

\begin{tabular}{|lcccccc}
\hline Source & $\begin{array}{c}\text { No. bacteria } \\
\text { at time zero } \\
\times 10^{6}\end{array}$ & $\begin{array}{c}\text { Maximum } \\
\text { bacterial } \\
\text { number } \\
\times 10^{6}\end{array}$ & $\begin{array}{c}\text { Time after } \\
\text { inoculation } \\
h\end{array}$ & $\begin{array}{c}\text { Max.bact. no. } \\
\text { Initial no. }\end{array}$ & $\begin{array}{c}\text { Max. no. } \\
\text { flagellates } \\
\times 10^{4}\end{array}$ & $\begin{array}{c}\text { No. flag. } \\
\text { No.bact. }\end{array}$ \\
\hline Isochrysis galbana & 0.21 & 6.61 & 81 & 31.5 & 0.81 & 0.123 \\
Skeletonema costatum & 0.21 & 7.11 & 69 & 33.9 & 1.78 & 0.250 \\
Scrippsiella trochoidea & 0.48 & 15.5 & 48 & 32.3 & 1.22 & 0.079 \\
Thalassiosira angstii & 0.48 & 22.8 & 72 & 47.5 & 1.26 & 0.055 \\
Isochrysis galbana & 0.48 & 11.1 & 72 & 23.1 & 1.01 & 0.091 \\
Skeletonema costatum & 0.48 & 16.2 & 48 & 33.8 & 1.46 & 0.090 \\
Chaetocerostricornatum & 0.48 & 23.4 & 72 & 48.8 & 2.25 & 0.096 \\
Mean & 0.345 & 14.674 & 66 & 35.84 & 1.40 & 0.112 \\
S.D. & & 6.83 & 12.84 & 9.18 & 1.18 & 0.064 \\
\hline
\end{tabular}

siosira angstii, $10.8 \mathrm{mg} \quad \mathrm{l}^{-1}$ from Scrippsiella trochoidea, $11.9 \mathrm{mg} \mathrm{l}^{-1}$ from Skeletonema costatum, $13.0 \mathrm{mg} \mathrm{l}^{-1}$ from Chaetoceros tricornutum and approximately $12.0 \mathrm{mg} \mathrm{l}^{-1}$ from Isochrysis galbana cells; it is clear that this resulted in the development of a mean peak bacterial population of $14.67 \times 10^{6} \mathrm{cells} \mathrm{m}^{-1}$ in approximately $66 \mathrm{~h}$ at $10^{\circ} \mathrm{C}$. This represents an average increase of approximately 36 times the bacterial population in the seawater after inoculation of phytoplankton detritus, and was followed by the development of a flagellate population which reached a mean peak density of $1.40 \times 10^{4}$ cells $\mathrm{ml}^{-1}$. This value is approximately $0.11 \%$ of the bacterial numbers. The ratio of numbers of flagellates to bacteria is, however, very variable due in part to the fact that the flagellate population was a mixed one with a small number of large flagellates in some cultures and large numbers of small flagellates in others. There can also be a good deal of variability in the relative proportions of bacterial rods and cocci and in their cell dimensions during the course of incubation. For this reason it is necessary to correct all the data for cell volumes (p. 125) and to express the relative proportions of both bacteria and micro-flagellates in terms of calculated biomass.
Fig. 2. Dry biomass of bacteria and flagellates $\left(\mathrm{mg} \mathrm{l}^{-1}\right)$ as a function of incubation time (d) in seawater at $10^{\circ} \mathrm{C}$. Thalassiosira angstii $112.12 \mathrm{mg}$ carbon $\mathrm{1}^{-1}$; Chaetoceros tricornutum (13.02 $\mathrm{mg}$ carbon $\mathrm{l}^{-1}$ ); Scrippsiella trochodea $(10.76$ mg carbon $1^{-1}$ ); Skeletonema costatum $\left(11.86 \mathrm{mg}\right.$ carbon $\left.\mathrm{I}^{-1}\right)$; Isochrysis galbana $(12.0 \mathrm{mg}$ carbon $1^{-1}$ ). Relation between maximal bacterial biomass and maximal flagellate biomass $(\mathrm{Y}=0.0122+0.0924 \times$; $r=0.8262 ; n=7$ )
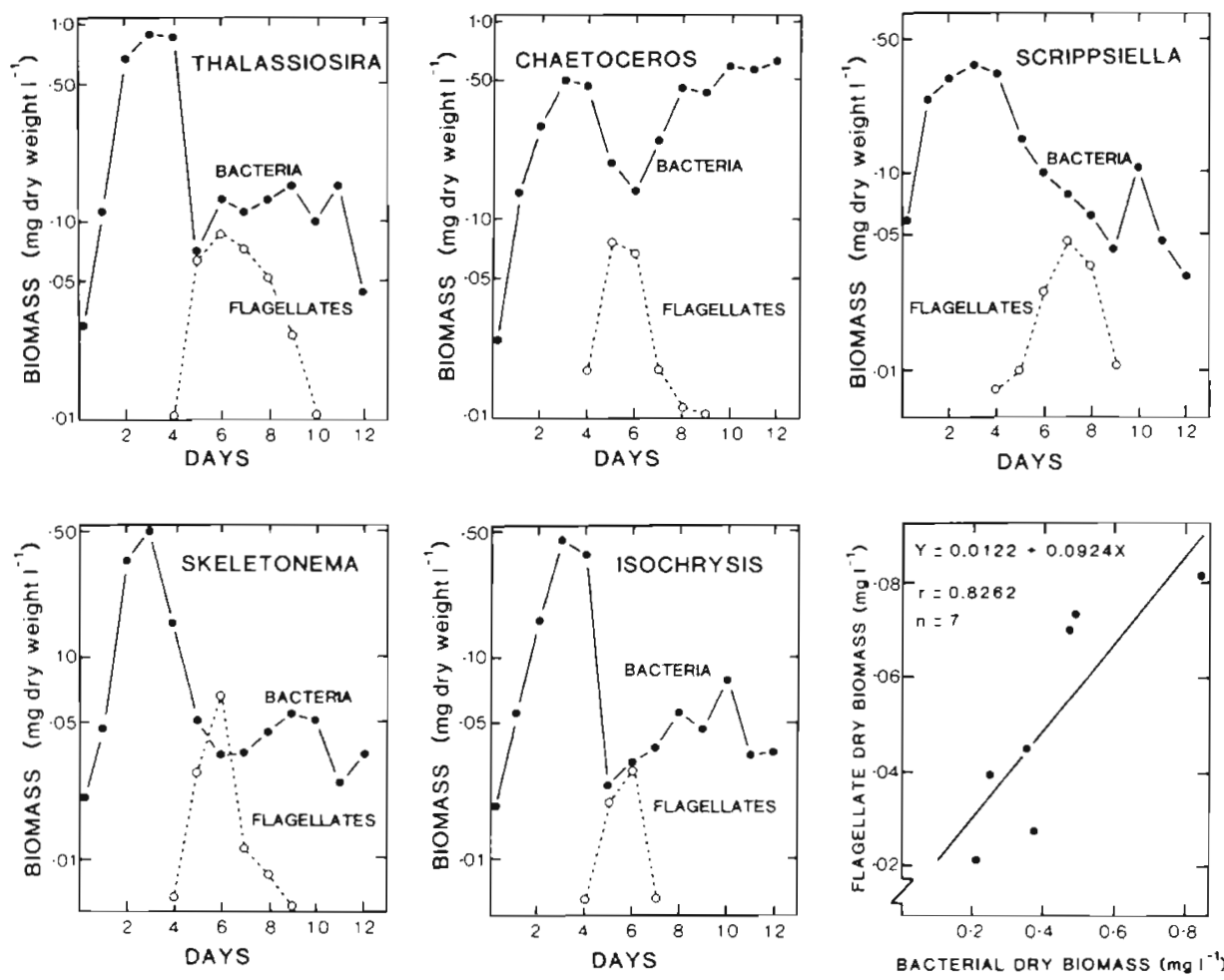
Table 2. Relation between carbon added from phytoplankton cell debris, and dry biomass of bacteria and micro-flagellates which appeared in seawater incubation media held at $10^{\circ} \mathrm{C}$. The carbon equivalent of dry bacterial biomass is taken as $50 \%$ (Luria, 1960) and has been used to calculate the ratio between standing stock of bacteria and carbon in phytoplankton cell debris. The ratio between standing stock of flagellates and bacterial biomass is also shown. Compiled from several incubation experiments including that illustrated in Fig. 2

\begin{tabular}{|c|c|c|c|c|c|c|c|}
\hline \multirow[t]{2}{*}{ Source } & \multicolumn{2}{|c|}{$\begin{array}{l}\text { Added carbon } \\
\qquad\left(\mathrm{mg} \mathrm{l}^{-1}\right)\end{array}$} & \multicolumn{2}{|c|}{$\begin{array}{c}\text { Calculated maximum } \\
\text { standing stock } \\
\text { of bacteria }\left(\mathrm{mg} \mathrm{l}^{-1}\right)\end{array}$} & \multirow{2}{*}{$\begin{array}{l}\text { Calculated } \\
\text { maximum } \\
\text { standing stock } \\
\text { of flagellates } \\
\left(\mathrm{mg} \mathrm{l}^{-1}\right) \\
\text { Biomass }\end{array}$} & \multirow[t]{2}{*}{$\begin{array}{l}\frac{\text { Bacterial C }}{\text { Detrital C }} \\
\quad \times 100\end{array}$} & \multirow[t]{2}{*}{$\begin{array}{c}\frac{\text { Flag. biomass }}{\text { Bact. biomass }} \\
\times 100\end{array}$} \\
\hline & $\begin{array}{l}\text { Mean } \\
\text { DOC }\end{array}$ & $\begin{array}{l}\text { Measured } \\
\text { total }\end{array}$ & Biomass & Carbon & & & \\
\hline Thalassiosira angstii & 3.57 & 12.12 & 0.843 & 0.422 & 0.081 & 3.48 & 9.61 \\
\hline Chaetoceros tricornutum & 4.03 & 13.02 & 0.480 & 0.240 & 0.074 & 1.84 & 15.42 \\
\hline Scrippsiella trochoidea & 2.53 & 10.76 & 0.338 & 0.169 & 0.045 & 1.57 & 13.31 \\
\hline \multirow[t]{2}{*}{ Skeletonema costatum } & 5.5 & 11.86 & 0.475 & 0.238 & 0.070 & 2.01 & 14.74 \\
\hline & 3.45 & 8.55 & 0.228 & 0.114 & 0.039 & 1.33 & 17.11 \\
\hline \multirow[t]{2}{*}{ Isochrysis galbana } & - & 12.0 & 0.366 & 0.183 & 0.027 & 1.53 & 7.38 \\
\hline & 3.05 & 8.20 & 0.212 & 0.106 & 0.021 & 1.29 & 9.91 \\
\hline \multicolumn{8}{|l|}{ Seawater controls } \\
\hline$N=6$ & 1.95 & 4.400 & 0.028 & 0.014 & - & 0.318 & - \\
\hline S.D. & 0.171 & 0.298 & 0.016 & 0.008 & & & \\
\hline Mean & 3.68 & 10.94 & 0.420 & 0.210 & 0.051 & 1.86 & 12.50 \\
\hline S.D. & 1.02 & 3.30 & 0.214 & 0.107 & 0.024 & 0.76 & 3.58 \\
\hline
\end{tabular}

The biomass of bacteria and flagellates which colonised the incubation media following the addition of phytoplankton debris is shown in Fig. 2. It is evident that in each case there was an initial rapid increase in bacterial biomass reaching a maximum on Day 3 of some 0.2 to $0.8 \mathrm{mg} \mathrm{l}^{-1}$, depending partly on the concentration of phytoplankton debris added at the beginning of the incubation. This phase was followed by an increase in the biomass of flagellates, many of which are known to graze on bacteria (Fenchel, 1969, 1970) and which were probably responsible for the decline in the standing stock of bacteria in the incubation media. It is noteworthy that in many cases the small flagellates which dominated the incubation media were apparently unable to utilise the large bacterial rods which subsequently increased in the later phases of the incubation experiments without a corresponding increase in flagellates.

The relation between the maximum standing stock of bacteria and the phytoplankton debris in the incubation media, and between flagellate and bacterial biomass in a series of incubation experiments on a variety of phytoplankton sources is summarised in Table 2. If the bacterial carbon comprises $50 \%$ of the dry biomass (Luria, 1960), it can be seen that the maximum standing stock of bacterial carbon attained in the incubation media is $1.86 \pm 0.76 \%$ of that in the phytoplankton. The ratio of flagellate biomass to bacterial biomass was 7 to $15 \%$ with a mean of $12.50 \pm 3.58 \%$ which is similar to the value of $10 \%$ which we have obtained in incubation experiments based on kelp detritus (Linley et al., 1981; Linley and
Newell, 1981; Stuart et al., 1981). The relation between biomass and flagellates and that of bacteria in the culture media is shown in Fig. $2(F)$ in which the equation of the regression is $\mathrm{Y}=0.0122+0.0924 \mathrm{X}$ ( $\mathrm{r}$ $=0.8262 ; \mathrm{N}=7$ ) for the pooled data from all the phytoplankton incubation experiments. Micro-flagellates thus appear to attain a maximum biomass of $10 \%$ of the bacterial biomass despite a wide variety of sources of detritus.

\section{Fate of Particulate Debris}

The particulate component of the debris from each of the phytoplankton sources underwent a well-defined sequence of initial aggregation into larger clumps over a period of $7 \mathrm{~d}$, followed by a phase of slow utilisation. This initial phase of aggregate formation can best be illustrated in a multidimensional form in which particle size and time of incubation are plotted on the $\mathrm{X}_{1}$ and $\mathrm{X}_{2}$ axes, and particle concentration (ppm by volume) on the $\mathrm{Y}$ axis. The resultant response surface can then be represented as a projection or contour diagram as is shown in Figs. 3 and 4.

Fig. 3 shows the response surface and its contour projection for Chaetoceros tricornutum debris which had been incubated for $7 \mathrm{~d}$ at $10^{\circ} \mathrm{C}$ in seawater. The initial size of the debris supplied in the incubation experiment was in the range 1.59 to $4.00 \mu \mathrm{m}$, and it can be seen from this sterilised control series that there was little change in particle distribution throughout the $7 \mathrm{~d}$ incubation. 

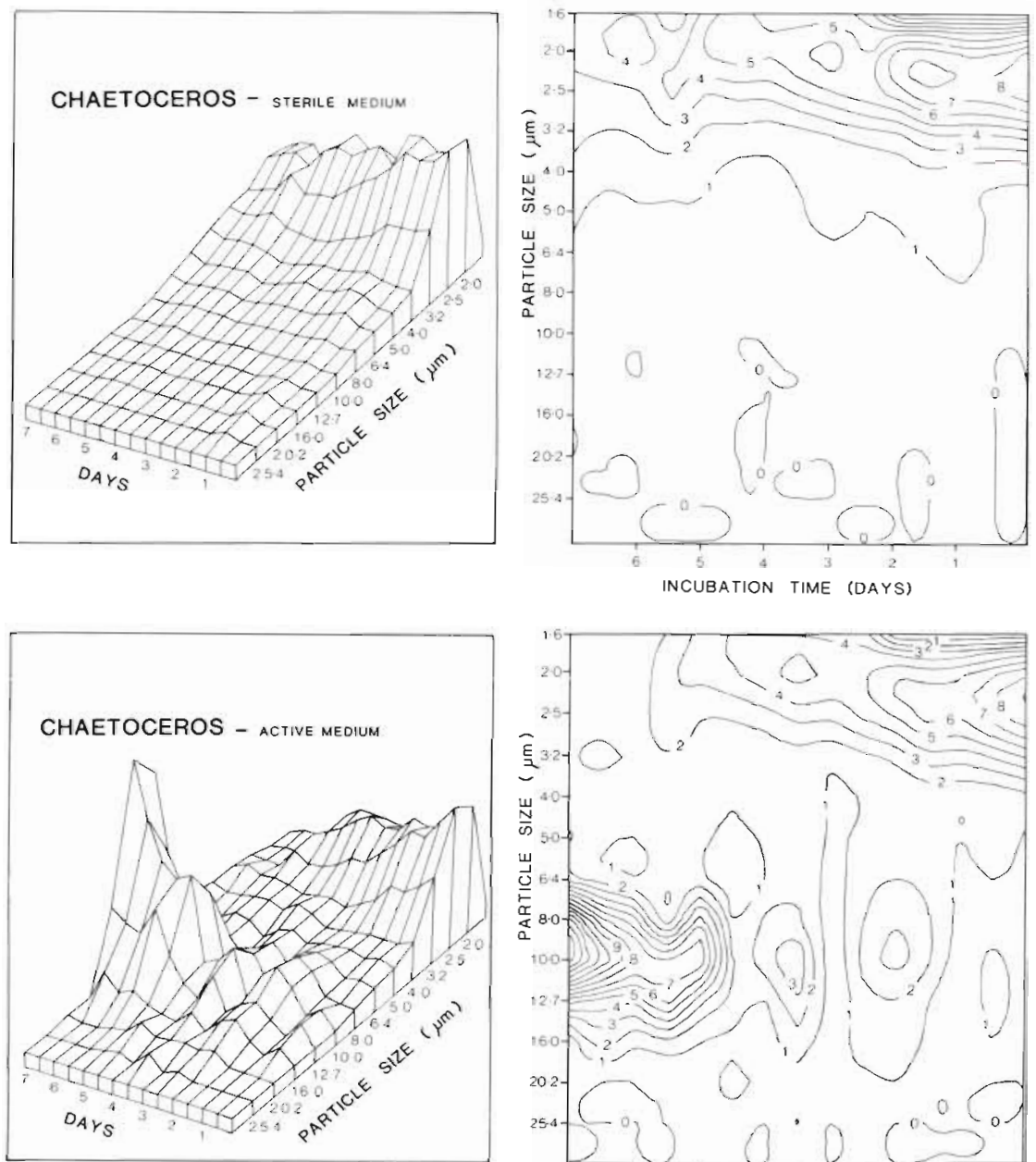

Fig. 3. Left: Response surface relating the effects of time of incubation $\left(X_{1}, d\right)$ on particle size distribution $\left(\mathrm{X}_{2}\right.$, particle diameter, $\mu \mathrm{m})$ and particle concentration ( $\mathrm{Y}, \mathrm{ppm}$ by volume) in sterilised control media $\left(10^{\circ} \mathrm{C}\right)$ containing cell debris from Chaetoceros tricornutum. Right: Contour projection of response surface onto the $X_{1}-X_{2}$ axes. Note that there is little evidence of aggregation or utilisation of particles which were initially supplied in the size range $1.59-4.00 \mu \mathrm{m}$

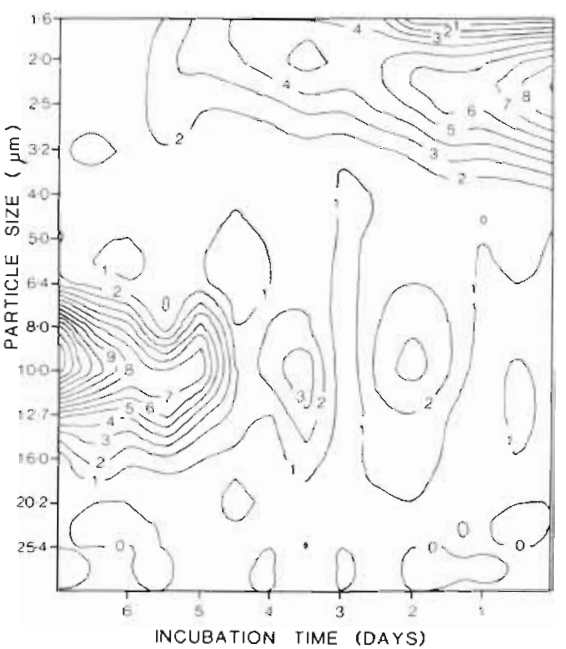

Fig. 4. Left: Response surtace relating the effects of time of incubation $\left(\mathrm{X}_{1}, \mathrm{~d}\right)$ on particle size distribution $\left(\mathrm{X}_{2}\right.$, particle diameter, $\mu \mathrm{m}$ ) and particle concentration ( $Y$, ppm by volume) in non-sterilised seawater $\left(10^{\circ} \mathrm{C}\right)$ containing cell debris from Chaetoceros tricornutum. Right: Contour projection of response surface onto the $\mathrm{X}_{1}-\mathrm{X}_{2}$ axes. Note progressive loss of fine particles from size range $1.59-4.00 \mu \mathrm{m}$ and aggregation into bacterio-organic complexes in size range $8.00-20.2 \mu \mathrm{m}$ over $7 \mathrm{~d}$ of incubation
In the non-sterilised series shown in Fig. 4, however, incubation in seawater resulted in a progressive loss of fine particles from channels 2 to 5 with a corresponding increase in concentration of large particles in the range 8.00 to $20.2 \mu \mathrm{m}$. At the end of $7 \mathrm{~d}$ at $10^{\circ} \mathrm{C}$, all the initially fine particles from the debris had formed aggregates of a very similar size to those which have been described in natural waters by Hobbie et al. (1972) and Linley and Field (1981).

This initial phase of aggregate formation which occurred in all non-sterile incubation media irrespective of the source of phytoplankton debris, clearly coincides closely with the development of bacteria and confirms the observations with scanning electron micrographs of the incubation media (p. 126). There is, however, very little evidence for a major utilisation of particulate matter during this phase so that it can be inferred indirectly from the data for particulate matter alone, that the dissolved organic component of phytoplankton debris is mainly utilised during the formation of bacterio-organic aggregates. Measurements of car- bon losses from the dissolved and particulate components of the degrading phytoplankton debris, however, allow a direct estimate of the source of carbon utilised during both the initial phase of aggregate formation and later decomposition phases of particulate matter, as well as yielding quantitative information on the carbon conversion efficiency of phytoplankton by marine bacteria.

\section{Losses of Carbon from Incubation Media}

Unfortunately, the formation of aggregates in incubation media containing debris from Isochrysis galbana was so variable that we were unable to obtain satisfactory replicate samples for carbon analysis. The dissolved organic carbon (DOC) in the filtrate and particulate carbon (PC) retained on a $1.2 \mu \mathrm{m} \mathrm{GF} / \mathrm{C}$ filter was, however, measured in the incubation media containing debris from Thalassiosira angstii, Scrippsiella trochoidea, Skeletonema costatum and 

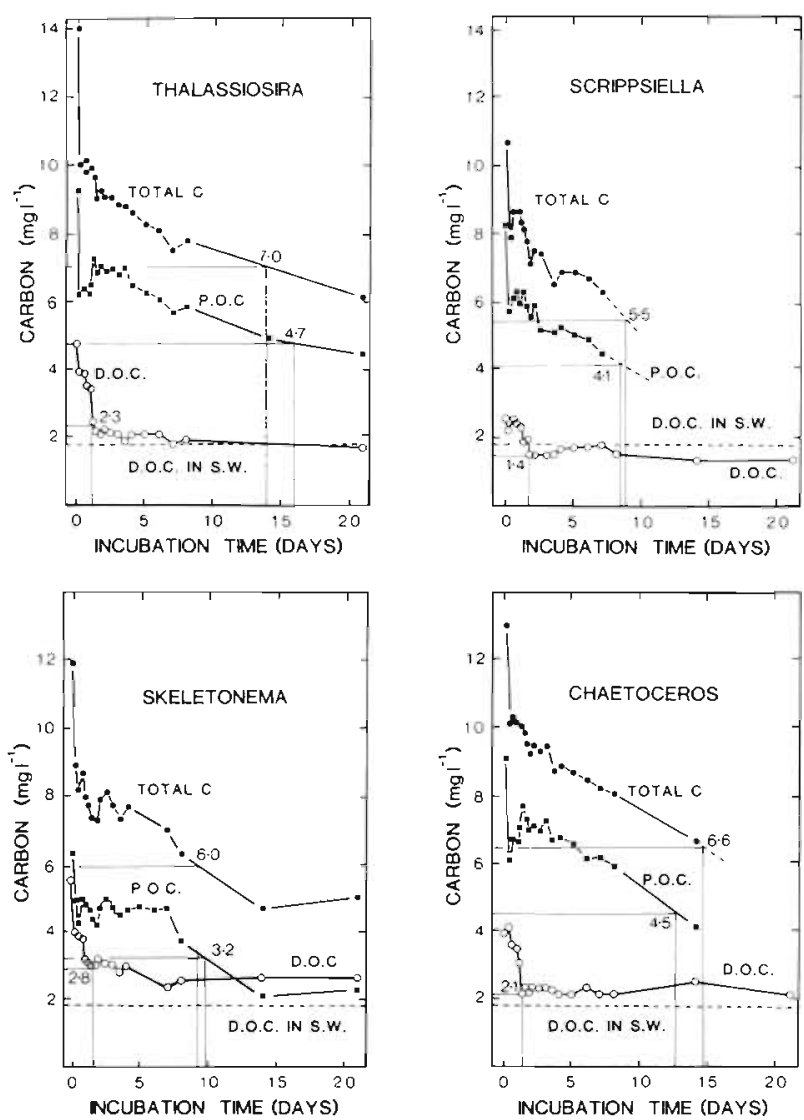

Fig. 5. Concentration of dissolved, particulate and total carbon in seawater incubated with cell debris from Thalassiosira angstii, Scrippsiella trochoidea, Skeletonema costatum and Chaetoceros tricornutum at $10^{\circ} \mathrm{C}$ for up to $21 \mathrm{~d}$. Mean DOC values for control seawater vessels are also shown. Note initial utilisation of the dissolved organic component which approaches the value for control seawater over a period of $3 \mathrm{~d}$ after which utilisation is mainly from the particulate component. $50 \%$ concentration and utilisation times are indicated

Chaetoceros tricornutum in one series of experiments for $14 \mathrm{~d}$ and in a second series for up to $25 \mathrm{~d}$. The results are shown in Fig. 5 and are of some interest since they both account for the lack of utilisation of particulate matter in the initial phases of aggregate formation, and also confirm results of other workers on the rate of utilisation of dissolved organic matter in natural waters.

The most obvious features of the data are that there is a rapid initial loss of both dissolved and particulate organic carbon from the media within $6 \mathrm{~h}$, well before any increase in bacteria was recorded. It seems likely that this represents an initial adsorption of a proportion of the cell debris onto the walls of the glass vessels rather than heterotrophic utilisation by the microorganisms. Subsequently, the dissolved organic component is utilised, but after approximately 2 to $3 \mathrm{~d}$ the rate of utilisation declines as the dissolved organic carbon approaches the mean value of $1.95 \mathrm{mg} \mathrm{l}^{-1}$ found in the control seawater vessels (see also Table 2 ). In the case of Skeletonema costatum and Chaetoceros tricornutum incubation experiments, the rate of utilisation of DOC became negligible at values considerably above that of seawater, implying that some of the dissolved organic carbon released during decomposition from these sources may be relatively refractory, much as has been described for the dissolved carbohydrates found in both freshwater and marine systems by Ogura (1972, 1975) and Ogura and Gotoh (1974). It will also be noticed that the particulate carbon fraction in the incubation media showed a phase of increase after the initial adsorption loss, implying a release from the walls of the vessel during the first few days of incubation. This effect is particularly important in an estimation of the utilisation of low initial concentrations of substrate carbon by the bacteria since the apparent utilisation of carbon from the medium may be relatively low during this phase.

Table 3 shows the $50 \%$ carbon concentration values in the incubation media and the corresponding times for $50 \%$ utilisation of dissolved, particulate and total carbon from each of the sources of phytoplankton debris. The mean $50 \%$ concentration values in the

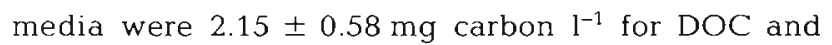
$4.13 \pm 0.66 \mathrm{mg}$ carbon $\mathrm{l}^{-1}$ for the particulate component. The total carbon was $6.28 \pm 0.66 \mathrm{mg} \mathrm{l}^{-1}$ so that the phytoplankton as a source of organic carbon comprises approximately $34 \%$ as a dissolved organic component and $65.8 \%$ as a particulate component. The $50 \%$ utilisation rates of the dissolved organic components and the particulate components are $1.56 \pm 0.13 \mathrm{~d}$ and $11.56 \pm 3.49 \mathrm{~d}$ respectively. That is, the DOC component is decomposed 7.41 times faster than the particulate component at $10^{\circ} \mathrm{C}$.

The carbon utilisation data thus suggest that the dissolved organic carbon component as a whole is utilised mainly during the first $3 \mathrm{~d}$ and coincides with the appearance and subsequent logistic growth phase of the free-living bacteria, whilst the particulate component may be utilised more slowly by the attached bacteria where biomass is in equilibrium with the mixed community of grazing flagellates (see also p. 126).

\section{Net Conversion Efficiency of Carbon from Phyto- plankton Debris to Bacterial Carbon}

The experiments which we have carried out on the utilisation of carbon from incubation media containing phytoplankton debris from a variety of sources, and the synchronous increase in biomass of microheterotrophs allow an estimate of the net carbon conversion efficiency from phytoplankton debris into bacteria. 
Table 3. $50 \%$ carbon concentration values and time taken for $50 \%$ utilisation of dissolved and particulate carbon from phytoplankton cell debris. Derived from Fig. 5

\begin{tabular}{|c|c|c|c|c|c|c|}
\hline \multirow[t]{2}{*}{ Source } & \multicolumn{3}{|c|}{$\begin{array}{l}50 \% \text { of initial carbon concentration } \\
\left(\mathrm{mg} \mathrm{l}^{-1}\right)\end{array}$} & \multicolumn{3}{|c|}{$\begin{array}{l}\text { Time for } 50 \% \text { utilisation } \\
\text { (d) }\end{array}$} \\
\hline & DOC & $\mathrm{PC}$ & Total & DOC & PC & Total \\
\hline Thalassiosira angstii & 2.3 & 4.7 & 7.0 & 1.5 & 16.0 & 14.0 \\
\hline Scrippsiella trochoidea & 1.4 & 4.1 & 5.5 & 1.75 & 8.0 & 9.0 \\
\hline Skeletonema costatum & 2.8 & 3.2 & 6.0 & 1.5 & 9.75 & 9.0 \\
\hline Chaetoceros tricornutum & 2.1 & 4.5 & 6.6 & 1.5 & 12.5 & 14.5 \\
\hline Mean & 2.15 & 4.13 & 6.28 & 1.56 & 11.56 & 11.63 \\
\hline S.D. & 0.58 & 0.66 & 0.66 & 0.13 & 3.49 & 3.04 \\
\hline$\%$ of total & 34.24 & 65.76 & - & 13.41 & 99.40 & - \\
\hline
\end{tabular}

The concentration of organic carbon in the control vessels and non-sterile experimental vessels is plotted as a function of time of incubation at $10^{\circ} \mathrm{C}$ in Fig. 6 . Each data point is the mean of 3 samples; the standard

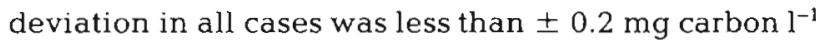
and was usually less than $\pm 0.1 \mathrm{mg} \mathrm{l}^{-1}$. The line has been drawn through the running mean of the data points and illustrates the initial adsorption and release phases in the control vessels. As pointed out above, this effect is of considerable importance in an estimation of the actual utilisation of carbon by the microheterotrophs in the incubation media. Since carbon is evidently released into the medium from Day 1 to Day 7 in vessels containing debris from Thalassiosira
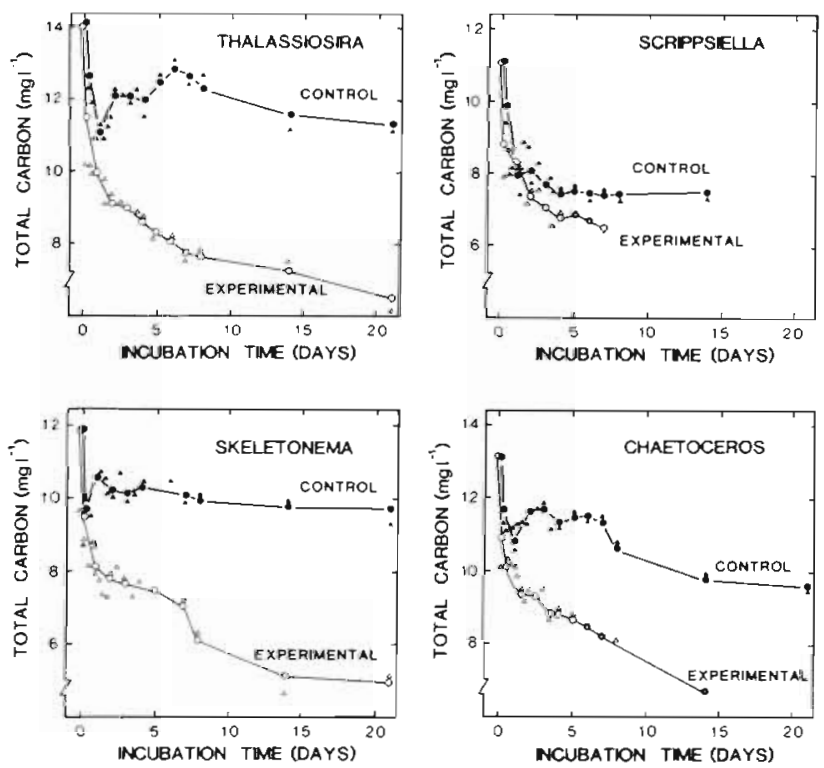

Fig. 6. Concentration of total carbon in sterilised (control) and non-sterilised seawater incubated with cell debris from Thalassiosira angstii, Scrippsiella trochoidea, Skeletonema costatum and Chaetoceros tricornutum at $10^{\circ} \mathrm{C}$ for up to $21 \mathrm{~d}$. Line fitted to running means for the data; the difference between the two has been used to calculate net utilisation of carbon by bacteria as a function of time in the non-sterilised media angstii, Skeletonema costatum and Chaetoceros tricornutum (see Fig. 6, controls), it is obvious that utilisation of carbon from the medium is considerably higher than would be assumed from the slope of the utilisation curve in the absence of a series of control vessels.

The difference between the carbon concentrations in the control vessels and in the non-sterile experimental vessels, together with the synchronous increase in bacterial carbon (calculated as $50 \%$ of the biomass; Table 2) is shown as a function of incubation time at $10^{\circ} \mathrm{C}$ in Fig. 7. It can be seen that the initial phase of bacterial increase up to Day 3 is accompanied by a
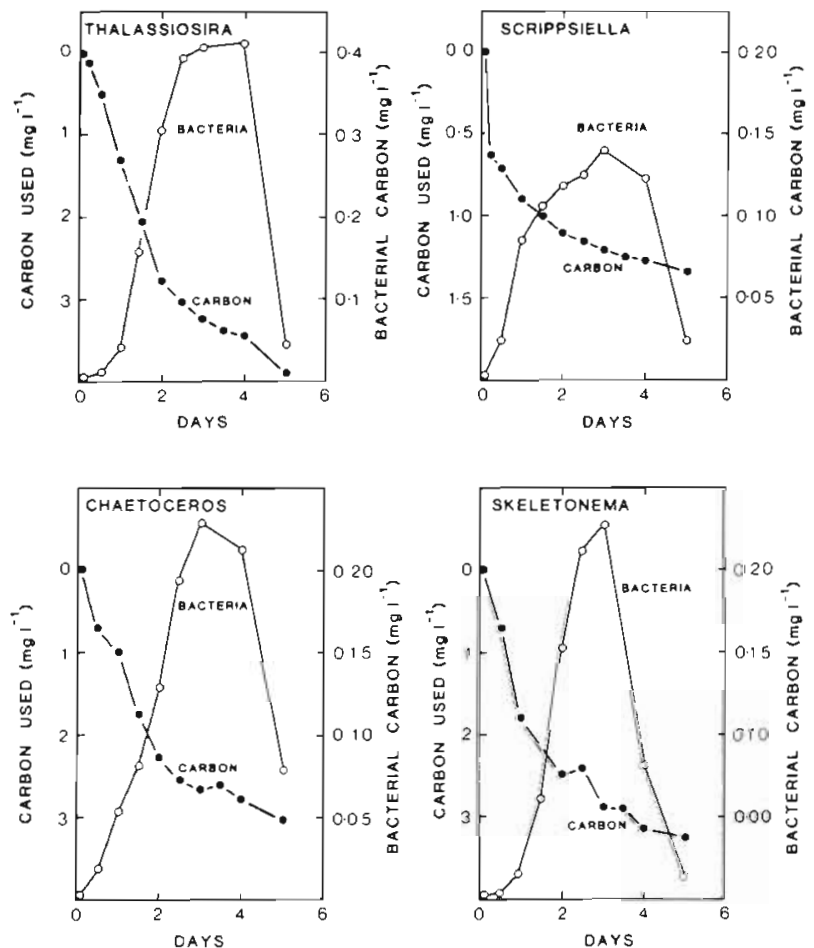

Fig. 7. Net carbon utilised and corresponding increase in the carbon equivalent of bacterial biomass in incubation media containing cell debris from Thalassiosira angstii, Scrippsiella trochoidea, Chaetoceros tricornutum and Skeletonema costatum 

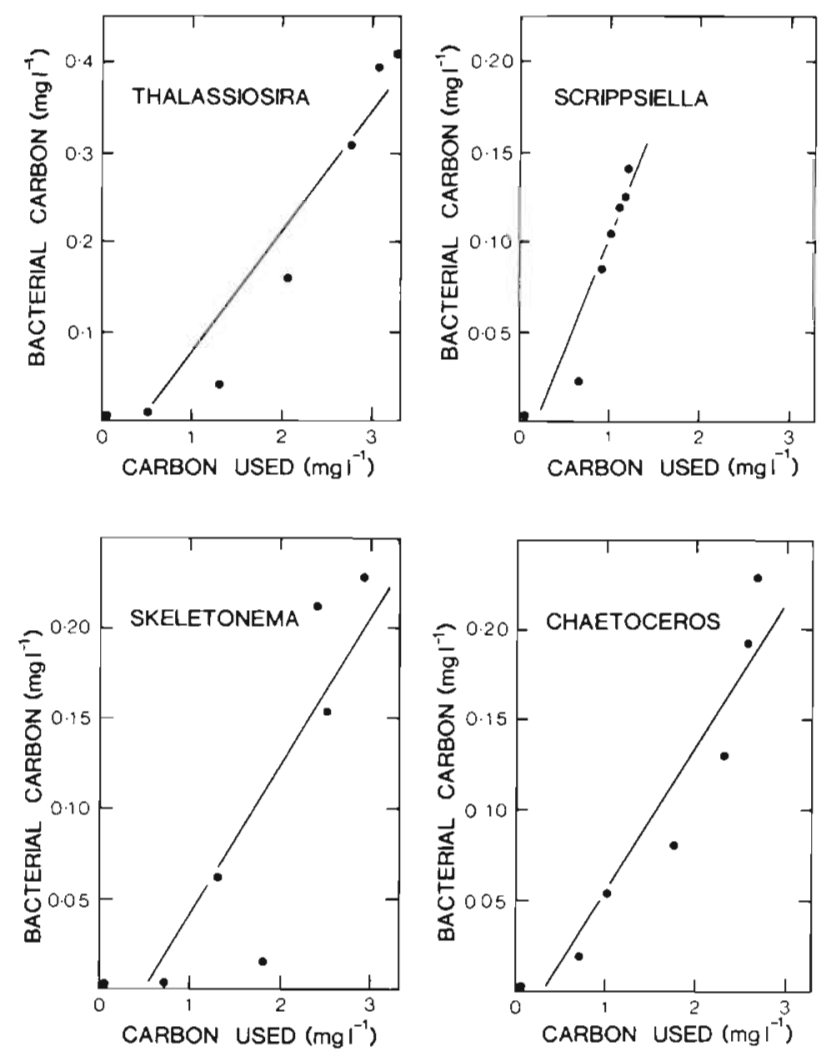

Fig. 8. Relationship between bacterial carbon production and detrital carbon utilisation in incubation media containing cell debris from Thalassiosira angstii, Scrippsiella trochoidea, Skeletonema costatum and Chaetoceros tricornutum. Data plotted from Fig. 7 up to the time at which flagellates appeared on Day 3. Equations for regressions for these and other incubation experiments are summarised in Table 4

major utilisation of carbon from each of the incubation media. After the appearance of grazing flagellates on Day 3, however, there was a rapid decline in bacterial biomass and a corresponding decrease in utilisation of carbon from the media. Because the standing stocks of bacteria are likely to be primarily limited by grazing flagellates from Day 3 onwards, it is not possible to relate bacterial production to carbon utilisation in the later phases of our incubation experiments. In the initial phases it is, however, possible to calculate the phytoplankton detrital carbon: bacterial carbon con- version efficiency directly from the relation between bacterial carbon incorporation and detrital carbon used. Some of these data for the curves in Fig. 7 are shown in Fig. 8 whilst the equations for the regressions for these are summarised in Table 4 . The mean value for the slope (b) is $0.09872 \pm 0.0267$. The bacterial carbon conversion efficiency (bacterial carbon incorporated/phytoplankton carbon used $\times 100$ ) established in the initial phase of decomposition of phytoplankton debris is thus $9.87 \pm 2.7 \%$. The regression equation for the pooled data irrespective of the source of phytoplankton debris is: $\mathrm{Y}=-0.0266+0.0984 \mathrm{X}$; $\mathrm{r}$ $=0.898 ; N=33(P=0.0005)$ which implies that as much as $90 \%$ of the carbon components from phytoplankton debris utilised up to Day 3 are mineralised by the bacteria and returned to the environment.

\section{CONCLUSION}

The data which we have presented on the rate of decomposition and conversion efficiency of phytoplankton debris by marine microorganisms shows that there is a succession in decomposer organisms. Primary microbial decomposers in the incubation experiments were bacterial cocci and rods, rather than fungi which have commonly been reported for freshwater detrital systems (Kaushik and Hynes, 1971; Lock and Hynes, 1976; Hayes, 1979). These were subsequently replaced by a smaller number of grazing flagellates, much as we have described elsewhere for the decomposition of debris from kelp (Linley et al., 1981; Linley and Newell, 1981; Lucas et al., 1981; Newell and Lucas, 1981; Stuart et al., 1981). The data show, moreover, that the maximal standing stock biomass of both bacteria and protozoans is related to the initial concentration of organic carbon in the detrital source. The mean bacterial standing stock of carbon was found to be $1.86 \pm 0.76 \%$ of the carbon supplied to the incubation media and subsequently declined as flagellates attained a biomass of approximately $10 \%$ of the bacterial biomass.

Synchronous measurement of the increase in bacterial biomass and utilisation of carbon from incubation

Table 4. Equations of regressions for bacterial carbon synthesised $\left(Y, \mathrm{mg} \mathrm{l}^{-1}\right)$ and carbon utilised $\left(\mathrm{X}, \mathrm{mg} \mathrm{l}^{-1}\right)$ from phytoplankton debris incubated at $10^{\circ} \mathrm{C}$ in seawater. Equation of the regression $\mathrm{Y}=\mathrm{a}+\mathrm{bX}$. Based on carbon utilisation and bacterial biomass up to the appearance of flagellates in the incubation media

\begin{tabular}{|lccccc|}
\hline \multicolumn{1}{|c}{ Source } & $\mathrm{a}$ & $\mathrm{b}$ & $\mathrm{r}$ & $\mathrm{N}$ & $\mathrm{P}$ \\
\hline Thalassiosira angstii & -0.0609 & 0.1348 & 0.9598 & 7 & 0.001 \\
Scrippsiella trochoidea & -0.0174 & 0.1199 & 0.9402 & 7 & 0.001 \\
Skeletonema costatum & -0.0410 & 0.0825 & 0.8687 & 7 & 0.01 \\
Chaetoceros tricornutum & -0.0250 & 0.0804 & 0.9471 & 7 & 0.001 \\
Isochrysis galbana & -0.0065 & 0.0760 & 0.9589 & 5 & 0.005 \\
\hline
\end{tabular}


media containing comparable concentrations of organic matter to those which can occur at the beginning of the decomposition phase of a dinoflagellate bloom in the English Channel shows that utilisation of the dissolved organic component, which comprises some $34.24 \%$ of the carbon in the phytoplankton detritus, occurs within approximately $3 \mathrm{~d}$ at $10{ }^{\circ} \mathrm{C}$. Utilisation of the dissolved organic carbon component is primarily responsible for the initial phase of bacterial colonisation and growth during which bacterio-particulate aggregates are formed much as have been described in natural waters by Hobbie et al. (1972) and Linley and Field (1981). The more refractory components, including particulate organic matter, are used more slowly and have a $50 \%$ utilisation time of approximately $11 \mathrm{~d}$ at $10^{\circ} \mathrm{C}$. Since organic carbon is converted to bacterial carbon with an efficiency of approximately $10 \%$, it follows that $1 \mu \mathrm{mol}$ of detrital carbon from phytoplankton is capable of supporting $1.2 \mu \mathrm{g}$ bacterial carbon production.

Other data for the carbon conversion efficiency of macrophyte detritus show a close similarity with the results obtained here based on debris from a variety of phytoplankton sources. The dissolved organic component released during fragmentation of the kelps Laminaria pallida and Ecklonia maxima yielded a bacterial biomass/carbon utilised ratio of $29.4 \%$ in summer and $12 \%$ in winter (Lucas et al., 1981; Newell and Lucas, 1981). If the dry bacterial biomass comprises $50 \%$ carbon (Luria, 1960), the mean carboncarbon conversion efficiency for the dissolved organic component of kelp is $10.35 \%$ compared with the value of $9.8 \%$ recorded here for the conversion of organic carbon during the initial phases of phytoplankton decomposition. Because the trophic interactions between the bacteria and flagellates are difficult to interpret quantitatively, it is not possible to calculate a similar carbon conversion efficiency for the more refractory particulate components of phytoplankton debris from our data. Nevertheless, comparison of the data with those which we have obtained for bacterial production based on kelp suggests that the conversion efficiency of the particulate component is likely to be only $20 \%$ of that of the dissolved material (Stuart et al., 1981)

The overall conversion efficiency for decomposition of phytoplankton cell debris is thus: $34.24 \mathrm{~g}$ of the detrital carbon represented by DOC are converted with an efficiency of $9.8 \%=3.355 \mathrm{~g}$ bacterial carbon, and $65.76 \mathrm{~g}$ of particulate carbon are converted with a probable efficiency of $2 \%=1.289 \mathrm{~g}$ bacterial carbon. This leads to a carbon budget for the decomposition of phytoplankton cell debris in which $100 \mathrm{~g}$ carbon yields $3.355+1.289=4.644 \mathrm{~g}$ of bacterial carbon, a figure which is generally lower than might be anticipated from the absorption efficiency of selected labile components released in small quantities by living phytoplankton (Smith et al., 1977; Wiebe and Smith, 1977 ; Larsson and Hagström, 1979; Mague et al., 1980). As pointed out (p. 125) some shrinkage during preparation for SEM measurements of cell dimensions could result in an under-estimate of the cell volume (Fuhrman, 1981), but this does not appear to be great in our preparations, and in any event is unlikely to account for the major differences between our observations on the conversion efficiencies of whole cell debris and those calculated from kinetic studies on simple labile components of dissolved organic matter released by phytoplankton. In fact, use of a coefficient of 0.5 for bacterial carbon from dry biomass probably results in an over-estimate of bacterial carbon fixation (p. 125) which more than compensates for the effects of cell shrinkage.

The carbon conversion budget for whole phytoplankton debris thus suggests that as much as $30.8 \%$ of the carbon is mineralised and returned to the environment within $3 \mathrm{~d}$ by the bacteria which initially colonise the material whereas the more refractory $64.4 \%$, comprising carbon in the particulate components of the cell debris, is mineralised within approximately $11 \mathrm{~d}$ by the bacteria which are characteristically associated with the decomposition phase of a phytoplankton bloom.

Acknowledgements. We are grateful to Director and staff of the Marine Biological Association, Plymouth, for provision of cultures of phytoplankton, and for extensive use of electron microscope facilities, and to Dr. P. J. Le B. Williams and Mr. P. Statham of the Dept. of Oceanography, University of Southampton, for advice and for use of their DOC analyser. Multidimensional analysis of the data for particulate matter was carried out partly at the University of Cape Town, and the work was completed at the Duke University Marine Laboratory, Beaufort. N. C. (USA), during tenure of National Institute of Health grant No ESO-1908. We are grateful to the Director and Joe and Celia Bonaventura for provision of facilities for this and other work. M.I. L. and R. C. N. are in receipt of funds from the Royal Society and E. A. S. L holds a NERC Postgraduate Studentship. Dr. P. J. Le B. Williams kindly commented on the draft manuscript.

\section{LITERATURE CITED}

Allen, H. L. (1973). Dissolved organic carbon: patterns of utilization and turnover in two small lakes. Int. Revue ges. Hydrobiol. 58: 617-624

Anderson, G. C., Zeutschel, R. P. (1970). Release of dissolved organic matter by marine phytoplankton in coastal and offshore areas of N. E. Pacific Ocean. Limnol. Oceanogr 15: 402-407

Andrews, P., Williams, P. J. le B. (1971). Heterotrophic utilization of dissolved organic compounds in the sea. III. Measurements of the oxidation rate and concentration of glu- 
cose and amino acids in seawater J. mar biol. Ass. U. K 51: $111-125$

Bell, W H., Mitchell, R. (1972). Chemostactic and growth responses of marine bacteria to algal extracellular products. Biol. Bull. mar. biol. Lab., Woods Hole 143: 265-277

Bell, W. H., Lang, J. M., Mitchell, R. (1974). Selective stimulation of marine bacteria by algal extracellular products Limnol. Oceanogr 19 (5): 833-839

Berman, T., Holm-Hansen, O. (1974). Release of photoassimilated carbon as dissolved organic matter by marine phytoplankton. Mar. Biol. 28: 305-310

Billen, G., Joiris, C., Wijnant, J., Gillian, G. (1980). Concentration and microbiological utilization of small organic molecules in the Scheldt Estuary, the Belgian coastal zone of the North Sea and the English Channel. Estuar. coast. mar. Sci. 11: 279-294

Calkins, G. N., Summers, F. M. (eds.) (1941). Protozoa in biological research, Columbia University Press, New York

Collins, K. J., Williams, P. J. Le B. (1977). An automated photochemical method for the determination of dissolved organic carbon in sea and estuarine waters. Mar. Chem. 5: 123-141

Crawford, C. C., Hobbie, J. E., Webb, K. L. (1974). The utilization of dissolved free amino acids by estuarine micro-organisms. Ecology 55: 551-563

Daley, R. J. (1979). Direct epifluorescence enumeration of native aquatic bacteria: Uses limitations and comparative accuracy. In: Costerton, J. W., Colwell, R. R. (eds.) Native aquatic bacteria: enumeration, activity and ecology. Amer. Soc. for Testing and Materials, pp. 29-45

Droop, M. R., Elson, K. G. R. (1966). Are pelagic diatoms free from bacteria? Nature, Lond. 211: 1096-1097

Fenchel, T. M. (1969). The ecology of marine meiobenthos. IV Structure and function of the benthic ecosystem, its chemical and physical factors and the microfauna communities with special reference to the ciliated protozoa Ophelia 6: 1-182

Fenchel, T. M. (1970). Studies on the decomposition of organic detritus derived from the turtle grass Thalassia testudinum. Limnol. Oceanogr. 15: 14-20

Fenchel, T. M., Jørgensen, B. B. (1976). Detritus food chains of aquatic ecosystems and the role of bacteria. Adv. microb. Ecol. 1: $1-49$

Fogg, G. E. (1971). Extracellular products of algae in freshwater. Arch. Hydrobiol. (Beih. Ergebn. Limnol.) 5: 1-25

Fuhrman, J. A. (1981). Influence of method on the apparent size distribution of bacterioplankton cells: Epifluorescence microscopy compared to scanning electron microscopy. Mar. Ecol. Prog. Ser. 5: 103-106

Gershey, R. M., Mackinnon, M. D., Moore, R. M., Williams, P. J. Le B. (1979). Comparison of three oxidation methods for the analysis of the dissolved organic carbon in seawater. Mar. Chem. 7: 289-306

Gordon, G. C., Robinson, G. G. C., Hondzel, L. L., Gillespie, D. C. (1973). A relationship between heterotrophic utilization of organic acids and bacterial populations in west Blue Lake, Manitoba. Limnol. Oceanogr. 18: 264-269

Hayes, A. J. (1979). The microbiology of plant litter decomposition. Sci. Progr., Lond. 66 (261): 25-42

Hellebust, J. A. (1965). Excretion of some organic compounds by marine phytoplankton. Limnol. Oceanogr. 10: 192-206

Hellebust, J. A. (1974). Extra-cellular products. In: Stewart, W. D. P. (ed.) Algal physiology and biochemistry. (Bot. Monographs) Blackwell Scientific Publications, Oxford, pp. 838-963

Hobbie, J. E. (1967). Glucose and acetate in freshwater: Concentrations and turnover rates. In: Gotterman, H. L.,
Clymo, R. S. (eds.) Chemical environment in aquatic habitat. North Holland Publishing Co., Amsterdam, pp. $245-251$

Hobbie, J. E., Crawford, C. C. (1969). Respiration corrections for bacterial uptake of dissolved organic compounds in natural waters. Limnol. Oceanogr. 14: 528-532

Hobbie, J. E., Daley, R. J., Jasper, S. (1977). Use of nuclepore filters for counting bacteria by fluorescence microscopy. Appl. environ. Microbiol. 35 (5): 1225-1228

Hobbie, J. E., Holm-Hansen, O., Packard, $T$ T., Pomeroy, L. R., Sheldon, R. W., Thomas, J. P., Wiebe, W. J. (1972). A study of the distribution and activity of micro-organisms in ocean water. Limnol. Oceanogr 17.544-555

Horne, A. J., Fogg, G. E., Eagle, D. J. (1969). Studies in situ of the primary production of an area of inshore Antarctic Sea. J. mar. biol. Ass. U. K. 49: 393-405

Iturriaga, R., Hoppe, H. G. (1977). Observations of heterotrophic activity on photoassimilated organic matter. Mar. Biol. 40: 101-108

Kaushik, N. K., Hynes, M. B. N. (1971). The fate of the dead leaves that fall into streams. Arch. Hydrobiol. 68 (4): $465-575$

Larsson, V., Hagström, A. (1979). Phytoplankton exudate release as an energy source for the growth of pelagic bacteria. Mar. Biol. 52: 199-206

Linley, E. A. S., Field, J. G. (1981). The nature and ecological significance of bacterial aggregation in West Coast kelp beds. Estuar coast. Shelf Sci. (in press)

Linley, E. A. S., Newell, R. C. (1981). Microheterotrophic communities associated with the degradation of kelp mucilage. Kieler Meeresforsch. (in press)

Linley, E. A. S., Newell, R. C., Bosma, S. A. (1981). Heterotrophic utilisation of mucilage released during fragmentation of kelp (Ecklonia maxima and Laminaria pallida). I. Development of microbial communities associated with the degradation of kelp mucilage. Mar. Ecol. Prog. Ser. 4: $31-41$

Lock, M. A., Hynes, H. B. N. (1976). The fate of 'dissolved' organic carbon derived from autumn-shed maple leaves (Acer saccharum) in a temperate hard-water stream. Limnol. Oceanogr. 21 (3): 436-443

Lucas, M. I., Newell, R. C., Velimirov, B. (1981). Heterotrophic utilisation of mucilage released during fragmentation of kelp (Ecklonia maxima and Laminaria pallida). II. Differential utilisation of dissolved organic components from kelp mucilage. Mar Ecol. Prog. Ser. 4; 43-55

Luria, S. E. (1960). The bacterial protoplasm: composition and organisation. In: Gunsalus, I. C., Stanier, R. Y (eds.) The bacteria, Vol. 1. Academic Press, New York, pp. 1-34

Mague, T. H., Friberg, E., Hughes, D. J., Morris, I. (1980). Extracellular release of carbon by marine phytoplankton; a physiological approach. Limnol. Oceanogr. 25 (2): 260-279

Newell, R. C., Lucas, M. I. (1981). The quantitative significance of dissolved and particulate organic matter released during fragmentation of kelp in coastal waters. Kieler Meeresforsch. (in press)

Ogura, N. (1972). Rate and extent of decomposition of dissolved organic matter in surface seawater. Mar Biol. 13: 89-93

Ogura, N. (1975). Further studies on decomposition of dissolved organic matter in coastal seawater Mar. Biol. 31: $101-111$

Ogura, N., Gotoh, T (1974). Decomposition of dissolved carbohydrates derived from diatoms of Lake Yuno-Ko. Int. Revue ges. Hydrobiol. 59 (1): 39-47

Pike, E. B., Carrington, E. G., Ashburner, P. A. (1972). An 
evaluation of procedures for enumerating bacteria in activated sludge. J. appl. Bact. 35: 309-321

Samuel, S., Shah, N. H., Fogg, G. E. (1971). Liberation of extracellular products of photosynthesis by tropical phytoplankton. J. mar. biol. Ass. U. K. 51: 793-798

Sharp, J. H. (1977). Excretion of organic matter by marine phytoplankton: Do healthy cells do it? Limnol. Oceanogr. 22: 381-399

Sieburth, J. McN. (1968). The influence of algal antibiosis on the ecology of marine micro-organisms. In: Droop, M. R. (ed.) Advances in microbiology, Vol. 1. Academic Press, New York, pp. 63-94

Smith, W. V., Jr (1974). The extracellular release of glycollic acid by a marine diatom. J. Phycol. 10: 30-33

Smith, W. O., Jr., Barber, R. T., Huntsman, S. A. (1977). Primary production off the coast of $\mathrm{N}$. W. Africa: excretion of dissolved organic matter and its heterotrophic uptake. Deep Sea Res. 24: 35-47

Sorokin, Y I., Kadota, H. (eds.) (1972). Techniques for the assessment of microbial production and decomposition in fresh waters, I. B. P. Handbook (23), Blackwell, Oxford

Stanier, R. Y., Doudoroff, M., Adelberg. E. A. (1970). General Microbiology, 3rd ed., Macmillan Press, New York

Strickland, J. D. H., Parsons, T. R. (1972). A practical handbook of seawater analysis, 2nd ed., Fish. Res. Bd Can., Bull. 167

Stuart, V., Lucas, M. I., Newell, R. C. (1981). Heterotrophic utilisation of particulate matter from the kelp Laminaria pallida. Mar. Ecol. Prog. Ser. 4: 337-348

Thomas, J. P. (1971). Release of dissolved organic matter from natural populations of marine phytoplankton. Mar. Biol. 11: 311-323

Troitsky, A. S., Sorokin, Y. I. (1967). On the methods of calculation of the bacterial biomass in water bodies. Trans. Inst. Biol. Inland waters. Acad. Sci. U.S.S.R. 19 : $85-90$

Wiebe, W. J., Smith, D. F. (1977). Direct measurement of dissolved organic carbon release by phytoplankton and incorporation by micro-heterotrophs. Mar. Biol. 42: 213-223

Williams, P. J. Le B. (1970). Heterotrophic utilization of dissolved organic compounds in the sea. I: Size distribution of population and relationship between respiration and incorporation of growth substrates. J. mar. biol. Ass. U. K. 50: $859-870$

Williams, P. J. Le B. (1973). On the question of growth yields of natural heterotrophic populations. Bull. Ecol. Res. Comm. (Stockholm) 17: 400-401

Wright, R. T., Hobbie, J. E. (1965). The uptake of organic solutes in lake water. Limnol. Oceanogr. 10: 22-28

Yurkovsky, A. K. (1971). Results of fraction investigation of the organic substances in the Baltic Sea. Proc. Joint Oceanogr. Assem. (Tokyo, 1970) 1971: 466-467 